\title{
Emended Description of Thermosipho africanus as a Carbohydrate-Fermenting Species Using Thiosulfate as an Electron Acceptor
}

\author{
GILLES RAVOT, ${ }^{1}$ BERNARD OLLIVIER, ${ }^{1 *}$ BHARAT K. C. PATEL, ${ }^{1,2}$ \\ MICHEL MAGOT, ${ }^{3}$ AND JEAN-LOUIS GARCIA ${ }^{1}$ \\ Laboratoire de Microbiologie ORSTOM, Université de Provence, 13331 Marseille Cedex $3,{ }^{1}$ and \\ Unité de Microbiologie, Sanofi Recherche, 31676 Labège Cedex, ${ }^{3}$ France, and Faculty of \\ Science and Technology, Griffith University, Nathan 4111, Brisbane, Australia ${ }^{2}$
}

\begin{abstract}
We found that Thermosipho africanus was able to ferment D-glucose, D-ribose, maltose, and starch, while D-galactose, fructose, and sucrose were utilized poorly. Acetate, $\mathrm{H}_{2}$, and $\mathrm{CO}_{2}$, as well as small amounts of ethanol and lactate, were end products of glucose metabolism in this organism. The presence of thiosulfate as an electron acceptor greatly improved growth and increased acetate production from the sugars. The genus Thermosipho is the only genus in the order Thermotogales that has been described as a non-carbohydrate fermenter. We propose that the description of the genus Thermosipho be emended because the only species in this genus, $T$. africanus, is a carbohydrate fermenter that is able to utilize thiosulfate as an electron acceptor.
\end{abstract}

The genera Thermotoga and Fervidobacterium are members of the order Thermotogales (8), a phylogenetically deeply branching member of the domain Bacteria. The members of these genera are considered carbohydrate fermenters which produce volatile fatty acids and other metabolic end products during fermentation. The genus Thermosipho (3) contains only one validly described species, Thermosipho africanus, whose type strain is strain Ob7 (= DSM 5309). It has been reported that in contrast to other members of the order Thermotogales, this organism does not ferment carbohydrates (3). During studies of numerous new members of the Thermotogales obtained from oil-producing wells (6), we observed that Thermosipho africanus was able to grow on D-glucose. The purchase of the culture which we used from the Deutsche Sammlung von Mikroorganism und Zellkulturen $\mathrm{GmbH}$, our extensive experience with culturing members of the Thermotogales (4-6), and the results of a microscopic examination which revealed cells that occurred singly, in pairs, and in chains of up to 12 cells enclosed in a sheath-like structure, a characteristic typical of Thermosipho africanus, all indicated clearly that the culture which we used had not been contaminated or mislabeled.

In our experiments, Thermosipho africanus was grown on basal medium containing (per liter) $1 \mathrm{~g}$ of $\mathrm{NH}_{4} \mathrm{Cl}, 0.3 \mathrm{~g}$ of $\mathrm{K}_{2} \mathrm{HPO}_{4}, 0.3 \mathrm{~g}$ of $\mathrm{KH}_{2} \mathrm{PO}_{4}, 0.2 \mathrm{~g}$ of $\mathrm{MgCl}_{2} \cdot 6 \mathrm{H}_{2} \mathrm{O}, 0.1 \mathrm{~g}$ of $\mathrm{CaCl}_{2} \cdot 2 \mathrm{H}_{2} \mathrm{O}, 0.5 \mathrm{~g}$ of cysteine- $\mathrm{HCl}, 10 \mathrm{~g}$ of $\mathrm{NaCl}, 0.1 \mathrm{~g}$ of $\mathrm{KCl}$, $0.5 \mathrm{~g}$ of $\mathrm{CH}_{3} \mathrm{COONa}, 1 \mathrm{~g}$ of yeast extract (Difco), $1 \mathrm{~g}$ of bio-Trypticase (bioMérieux), $10 \mathrm{ml}$ of a trace element solution (1), and $0.001 \mathrm{~g}$ of resazurin. This medium was made anaerobic and was buffered as described elsewhere (2). During growth, the cells were observed with a Nikon phase-contrast microscope. The concentrations of most of the end products of metabolism, including fatty acids and sulfide, were determined as described previously (2); the concentration of lactate was determined enzymatically (L-lactic acid test 139 084; Boehringer Mannheim GmbH, Mannheim, Germany). The organism was subcultured at least once under the same experimental conditions prior to inoculation.

\footnotetext{
* Corresponding author. Mailing address: Laboratoire de Microbiologie ORSTOM, Université de Provence, 3 Place Victor Hugo, 13331 Marseille Cedex 3, France. Phone: 33.91.10.64.80. Fax: 33.91.10.64.81.
}

When we repeated our experiments with D-glucose and a variety of other carbohydrates, we observed that Thermosipho africanus not only used D-glucose but also used a limited number of other carbohydrates, including D-ribose, starch, and maltose; D-galactose, fructose, and sucrose were poorly used (Table 1). In the absence of thiosulfate, $7.9 \mathrm{mM}$ acetate, 0.79 $\mathrm{mM}$ ethanol, $<0.2 \mathrm{mM}$ lactate, $16.8 \mathrm{mM} \mathrm{H}_{2}$, and $7.3 \mathrm{mM} \mathrm{CO}_{2}$ were produced and $7.2 \mathrm{mM}$ D-glucose was consumed. In the presence of $20 \mathrm{mM}$ thiosulfate, $12.4 \mathrm{mM}$ acetate, $1 \mathrm{mM} \mathrm{H}_{2}$, $14.6 \mathrm{mM} \mathrm{H}_{2} \mathrm{~S}$, and $15.5 \mathrm{mM} \mathrm{CO}_{2}$ were produced and $7.7 \mathrm{mM}$ glucose was consumed; ethanol production and lactate production were not detected. It was not possible to determine fermentation balances because an unknown peak was observed during the end product analysis; this unidentified peak was not a fatty acid or an alcohol, and its concentration was consistently higher in the absence of thiosulfate than in the presence of thiosulfate.

Members of the order Thermotogales, including Thermosipho africanus, have been reported to reduce elemental sulfur to sulfide during growth $(3,7,8)$. We found that when Thermotoga, Fervidobacterium, and Thermosipho species, in particular the hyperthermophilic species Thermotoga neopolitana and Thermotoga maritima, were grown on a complex medium containing D-glucose and thiosulfate, the cell densities and growth rates increased markedly (7). This stimulatory effect was not observed when sulfate was substituted for thiosulfate (7). We found that the better growth of Thermosipho africanus obtained with thiosulfate (Fig. 1) may have resulted directly from an increase in D-glucose oxidation as more acetate was produced from the same amount of substrate oxidized and no ethanol or lactate was detected. The ratio of the amount of acetate produced to the amount of glucose consumed was consistently higher in the presence of thiosulfate than in the absence of thiosulfate in all experiments. In addition, the decrease in the production of the unidentified compound in the presence of thiosulfate is further evidence that metabolism changed.

We also found that thiosulfate had a great impact on the growth of Thermosipho africanus on other carbohydrates (Table 1). The highly fermentable carbohydrates D-ribose, maltose, and starch and the poorly fermentable carbohydrates D-galactose, fructose, and sucrose all were better growth sub- 
TABLE 1. Carbohydrate fermentation by Thermosipho africanus type strain DSM 5309 in the absence and in the presence of thiosulfate

\begin{tabular}{|c|c|c|c|c|}
\hline \multirow[b]{2}{*}{ Carbohydrate $^{a}$} & \multicolumn{2}{|c|}{ Without thiosulfate } & \multicolumn{2}{|c|}{ With $20 \mathrm{mM}$ thiosulfate $\mathrm{c}^{c}$} \\
\hline & $\Delta \mathrm{OD}_{580}{ }^{b}$ & $\begin{array}{c}\text { Concn of acetate } \\
\text { formed }(\mathrm{mM})\end{array}$ & $\Delta O D_{580}$ & $\begin{array}{l}\text { Concn of acetate } \\
\text { formed }(\mathrm{mM})\end{array}$ \\
\hline Control $^{d}$ & 0.12 & 2.34 & 0.17 & 5.05 \\
\hline D-Glucose $\mathrm{e}^{c}$ & 0.26 & 7.47 & 0.63 & 17.05 \\
\hline Maltose $^{c}$ & 0.36 & 9.86 & 1.10 & 17.07 \\
\hline D-Ribose ${ }^{c}$ & 0.45 & 14.98 & 0.51 & 21.36 \\
\hline Starch $^{e}$ & 0.33 & 10.58 & 0.75 & 28.05 \\
\hline D-Galactose $\mathrm{e}^{\prime}$ & 0.16 & 3.04 & 0.38 & 8.27 \\
\hline Sucrose $^{f}$ & 0.13 & 4.15 & 0.52 & 9.51 \\
\hline D-Fructose $\mathrm{e}^{\prime}$ & 0.12 & 2.48 & 0.28 & 8.11 \\
\hline
\end{tabular}

"Other carbohydrates which did not result in increases in optical density or increases in the concentrations of the products of metabolism were $\mathrm{L}$-arabinose, cellulose, dulcitol, lactose, D-mannitol, L-rhamnose, L-sorbose, D-xylose, and Lxylose. The carbohydrates on which the organism grew were pure and did not contain carbohydrate impurities according to the manufacturers' notes on the product containers. All carbohydrates were used at a final concentration of $20 \mathrm{mM}$.

${ }^{b} \Delta \mathrm{OD}_{580}$, difference between the optical density at $580 \mathrm{~nm}$ after incubation for $48 \mathrm{~h}$ at $70^{\circ} \mathrm{C}$ and the optical density at $580 \mathrm{~nm}$ prior to incubation before the inoculum was added. The inoculum was prepared by subculturing the organism at least twice in carbohydrate-containing medium.

${ }^{c}$ In addition to increases in optical density, increases in the concentrations of end products and consumption of the carbohydrates were observed compared with the control containing no added carbohydrate.

${ }^{d}$ The control consisted of basal medium containing no added carbohydrate.

e Production of glucose was observed together with increases in the optical density and end product concentrations.

${ }^{f}$ Carbohydrates were poorly used; the concentrations of the end products were slightly higher than the concentrations in the controls.

strates in the presence of thiosulfate than in the absence of this compound (Table 1). Therefore, we concluded that thiosulfate has a far greater impact on the growth of Thermosipho africanus (and also other members of the Thermotogales) than elemental sulfur has (reference 7 and this study). It will be necessary to add thiosulfate to the medium as an electron acceptor in order to ensure more detailed phenotypic descriptions of the metabolic properties of these microorganisms, in particular the utilization of sugars.

On the basis of evidence presented above, we propose that Thermosipho africanus should be considered a carbohydratefermenting thermophilic anaerobe. As this is the only species in the genus Thermosipho, we also propose that the genus description should be emended to include this characteristic as a defining characteristic. The descriptions given below are for the most part based on the original descriptions (3).

Description of the genus Thermosipho. Thermosipho (Huber, Woese, Langworthy, Fricke, and Stetter 1989; emend. Ravot, Ollivier, Patel, Magot, and Garcia 1995) (Ther.mo.si'pho. Gr. fem. n. therme, heat; L. masc. n. sipho, tube; M.L. masc. n. Thermosipho, hot tube, referring to the sheath surrounding the bacteria). Cells are gram-negative rods that have an average length of 3 to $4 \mu \mathrm{m}$ and a width of about $0.5 \mu \mathrm{m}$. Each rod is surrounded by a sheath-like structure that balloons over the ends. The cells occur singly, in pairs, and in chains that are up to 12 cells long, depending on the growth phase. The rods tend to become large spheres in the stationary phase. Colonies are round and colorless. Growth occurs at temperatures between 35 and $77^{\circ} \mathrm{C}$ (optimum temperature, $75^{\circ} \mathrm{C}$ ) and at $\mathrm{pH}$ values between 6.0 and 8.0 (optimum pH, 7.2). Growth occurs in the presence of 0.11 to $3.6 \% \mathrm{NaCl}$. For heterotrophic growth under anaerobic conditions, complex organic material, such as yeast extract, peptone, or tryptone, is necessary. Uses D-glucose, maltose, starch, and D-ribose. Uses D-galactose, fructose,

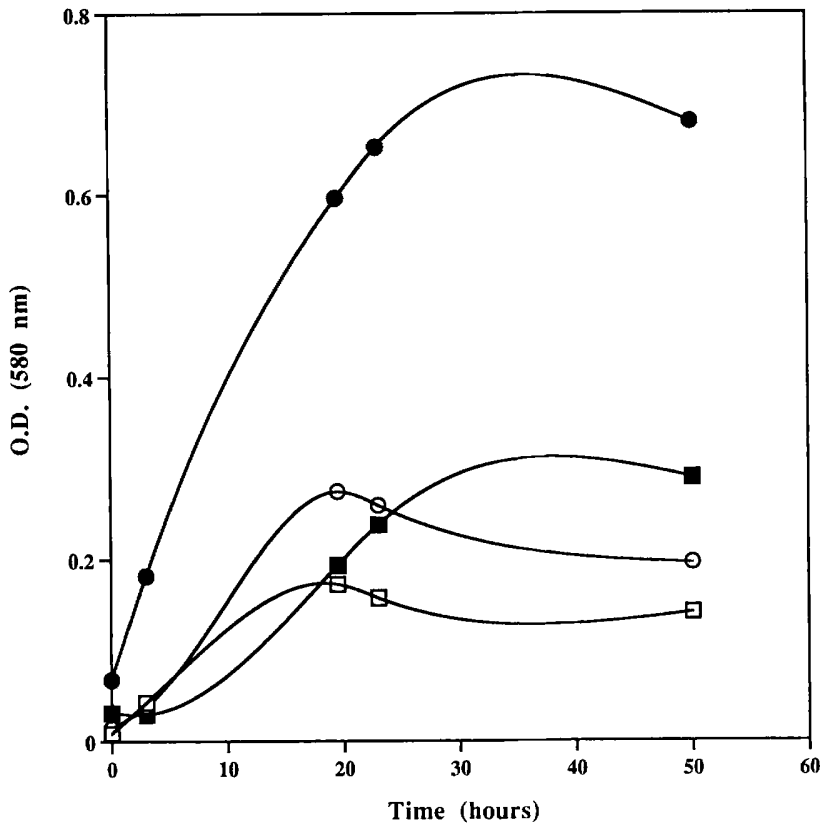

FIG. 1. Effect of thiosulfate on the growth of Thermosipho africanus cultivated in basal medium containing $1 \mathrm{~g}$ of yeast extract per liter and $1 \mathrm{~g}$ of bio-Trypticase per liter. Symbols: $\square$, control; $0,20 \mathrm{mM}$ thiosulfate; $\mathbf{\square}, 20 \mathrm{mM}$ glucose;, $20 \mathrm{mM}$ glucose plus $20 \mathrm{mM}$ thiosulfate. O.D. $(580 \mathrm{~nm})$, optical density at $580 \mathrm{~nm}$.

and sucrose poorly. Growth on all of these sugars is enhanced in the presence of thiosulfate. No growth occurs in the presence or absence of thiosulfate on the following substrates: D-mannitol, L-rhamnose, L-sorbose, D-xylose, L-xylose, lactose, L-arabinose, dulcitol, and cellulose. Acetate, $\mathrm{H}_{2}$, and $\mathrm{CO}_{2}$, as well as small amounts of ethanol, lactate, and an unidentified compound, are produced during glucose fermentation. Elemental sulfur and thiosulfate are reduced to sulfide. Growth is inhibited by hydrogen. Sensitive to lysozyme. Resistant to 10 $\mu \mathrm{g}$ of rifampin per $\mathrm{ml} ; 100 \mu \mathrm{g}$ of rifampin per $\mathrm{ml}$ inhibits growth. Does not cross-react serologically with Thermotoga maritima RNA polymerase antiserum. No isopranyl glycerol ether lipids are detected. $\mathrm{C}_{28}$ to $\mathrm{C}_{34}$ dicarboxylic fatty acids are present. The DNA base composition $(\mathrm{G}+\mathrm{C}$ content) is about $30 \mathrm{~mol} \%$.

The type species is Thermosipho africanus.

Description of Thermosipho africanus Huber, Woese, Langworthy, Fricke, and Stetter. Thermosipho africanus (af.ri.ca'nus. L. masc. adj. africanus, belonging to Africa, describing the place of isolation). The description of Thermosipho africanus is the same as the description of the genus Thermosipho. Lives in a shallow hydrothermal system at Obock, Djibouti, Africa.

The type strain is strain Ob7 (= DSM 5309).

We thank M.-L. Fardeau for helpful discussions.

This work was supported in part by a grant from Elf-Aquitaine (to G.R.).

\section{REFERENCES}

1. Balch, W. E., G. E. Fox, L. J. Magrum, C. R. Woese, and R. S. Wolfe. 1979. Methanogens: reevaluation of a unique biological group. Microbiol. Rev. 43: 260-296.

2. Fardeau, M.-L., J.-L. Cayol, M. Magot, and B. Ollivier. 1993. $\mathrm{H}_{2}$ oxidation in the presence of thiosulfate by a Thermoanaerobacter strain isolated from an oil-producing well. FEMS Microbiol. Lett. 113:327-332.

3. Huber, R., C. R. Woese, T. A. Langworthy, H. Fricke, and K. O. Stetter. 1989. Thermosipho africanus gen. nov. represents a new genus of thermophilic eubacteria within the "Thermotogales." Syst. Appl. Microbiol. 12:32-37. 
4. Huser, B. A., B. K. C. Patel, H. W. Morgan, and R. M. Daniel. 1986. Isolation and characterization of a novel extremely thermophilic, anaerobic chemoorganotrophic eubacterium. FEMS Microbiol. Lett. 37:121-127.

5. Patel, B. K. C., H. W. Morgan, and R. M. Daniel. 1985. Fervidobacterium nodosum gen. nov. and sp. nov., a new chemoorganotrophic, caldoactive. anaerobic bacterium. Arch. Microbiol. 141:63-69.

6. Ravot, G., M. Magot, M.-L. Fardeau, B. K. C. Patel, G. Prensier, A. Egan, J.-L. Garcia, and B. Ollivier. 1995. Thermotoga elfii sp. nov., a novel thermo- philic bacterium from an African oil-producing well. Int. J. Syst. Bacteriol. 45:308-314.

7. Ravot, G., B. Ollivier, M. Magot, B. K. C. Patel, J.-L. Crolet, M.-L. Fardeau, and J.-L. Garcia. 1995. Thiosulfate reduction, an important physiological feature shared by members of the order Thermotogales. Appl. Environ. Microbiol. 61:2053-2055.

8. Stetter, K. O., G. Fiala, G. Huber, R. Huber, and A. Segerer. 1990. Hyperthermophilic microorganisms. FEMS Microbiol. Rev. 75:117-124. 